\title{
Método rápido para extração de DNA de Puccinia kuehnii
}

\author{
Valter Miotto Alessio ${ }^{1}$, Hermann Paulo Hoffmann ${ }^{1}$, Monalisa Sampaio Carneiro ${ }^{1}$
}

${ }^{1}$ Universidade Federal de São Carlos - UFSCar, Centro de Ciências Agrárias - CCA, Departamento de Biotecnologia e Produção Vegetal e Animal, Via Anhanguera, km 174 - Caixa Postal 153, CEP 13600970, Araras - São Paulo.

Monalisa Sampaio Carneiro (monalisa@cca.ufscar.br)

Data de chegada: 06/06/2012. Aceito para publicação em: 10/07/2013.

\section{RESUMO}

Alessio, V.M.; Hoffmann, H.P.; Carneiro, M.S. Método rápido para extração de DNA de Puccinia kuehnii. Summa Phytopathologica, v.39, n.3, p.198-200, 2013.

Foi desenvolvido um método eficiente, rápido e de baixo custo para extração de DNA de Puccinia kuehnii, patógeno causador da ferrugem alaranjada em cana-de-açúcar, importante doença de recente emergência no ocidente. O protocolo de extração foi testado em esporos recém-coletados e em esporos armazenados a $-80^{\circ} \mathrm{C}$ por 7 meses. Com uma quantidade inicial de $15 \mathrm{mg}$ de esporos foi obtido concentrações médias de DNA variando de $880,8 \mathrm{mg} / \mathrm{mL}$ a $1115,9 \mathrm{mg} / \mathrm{mL}$. A amplificação do DNA extraído foi positiva para as amostras avaliadas.

Palavras-chave adicionais: Ferrugem alaranjada, PCR, Saccharum spp., esporos, preservação.

\section{ABSTRACT}

Alessio, V.M.; Hoffmann, H.P.; Carneiro, M.S. A rapid DNA extraction method for Puccinia kuehnii. Summa Phytopathologica, v.39, n.3, p.198-200, 2013.

An efficient, rapid and low-cost DNA extraction method was developed for Puccinia kuehnii, the causal pathogen of orange rust in sugarcane, an emerging disease in the western hemisphere. The extraction protocol was tested for recently collected spores, as well as for spores stored at $-80^{\circ} \mathrm{C}$ for 7 months. An initial amount of $15 \mathrm{mg}$ of spores led to average DNA concentrations ranging from $880.8 \mathrm{mg} / \mathrm{mL}$ to 1115.9 $\mathrm{mg} / \mathrm{mL}$. Amplification of the extracted DNA was positive for the evaluated samples.

Additional keywords: Orange rust, PCR, Saccahrum spp., spores, preservation.

As duas ferrugens de maior importância econômica que afetam a cana-de-açúcar (Saccharum spp.) são a ferrugem marrom e a ferrugem alaranjada causadas pelos fungos Puccinia melanocephala Syd. \& P. Syd. e P. kuehnii (W. Krüger) E. J. Butler, respectivamente (2).

A ferrugem alaranjada é caracterizada por causar manchas cloróticas nas folhas mais jovens que progridem rapidamente para lesões que se rompem, formando uredínios comumente chamados de pústulas as quais são observadas geralmente na face abaxial das folhas. As pústulas podem ocorrer distribuídas por toda a superfície da folha, porém, agrupadas e próximas ao ponto de inserção no colmo. Em variedades altamente suscetíveis, as lesões coalescem causando necrose das folhas. A doença difere da ferrugem marrom por apresentar pústulas ligeiramente arredondadas de coloração laranja distribuídas pelas folhas de maneira desigual (5).

A ferrugem alaranjada não apresentava grande importância econômica até o ano de 2000 quando perdas na Austrália, em razão da infecção da variedade Q124 que ocupava grande parte dos canaviais do país, chegaram a $40 \%$ em toneladas de cana por hectare o que representou perdas de 150 a 210 milhões de dólares para o setor (5, $6)$.

A primeira ocorrência reportada no Brasil foi à região de Araraquara em dezembro de 2009 em um campo de multiplicação de clones précomerciais (cv. Centauro). Também já foi reportada a suscetibilidade das variedades comerciais SP89-1115, RB72454 e SP84-2025 (1). Diante desse novo panorama, a ferrugem alaranjada ganhou destaque, porém, as condições de conservação, recuperação e germinação ainda não estão bem estabelecidas (1). Nesse sentido, torna-se importante o desenvolvimento de metodologias que viabilizem estudos futuros desse fitopatógeno. $\mathrm{O}$ isolamento do DNA é pré-requisito fundamental para diversas técnicas de biologia molecular e até o momento, as metodologias apresentadas para o isolamento e purificação de DNA genômico de P. kuehnii foram baseadas em kits comerciais $(2,3,4)$.

O objetivo deste trabalho foi desenvolver um método de extração de DNA de esporos de P. kuehnii em amostras recém coletadas e amostras preservadas por congelamento, avaliando-se a eficiência do método através da PCR (Polymerase Chain Reaction) utilizando primers específicos para identificação de $P$. kuehnii.

Os esporos de P. kuehnii foram coletados de clones de cana-deaçúcar infectados naturalmente no Programa de Melhoramento Genético de Cana-de-Açúcar da UFSCar (PMGCA/RIDESA) com ajuda de um pincel e armazenados em microtubos de $2 \mathrm{~mL}$ até o momento da extração. Inicialmente foram realizadas cinco coletas em julho de 2010 , os esporos foram imediatamente congelados em ultrafreezer a $-80^{\circ} \mathrm{C}$ sem nenhum tipo de tratamento especial durante sete meses. Uma nova coleta de esporos foi realizada a partir da variedade SP89-1115 os quais foram submetidos à extração de DNA, 24 horas após a coleta. 
A metodologia foi desenvolvida a partir do protocolo de extração de DNA utilizado por Villaréal et al. (8). Para cada amostra, aproximadamente $15 \mathrm{mg}$ de esporos foram suspendidos em $200 \mu \mathrm{lde}$ tampão de extração (Tris-HCl 0,1 M, CTAB 2\%, NaCl 0,8 M, EDTA $20 \mathrm{mM}$ e PVP $0,1 \%$ ) em um microtubo de $2 \mathrm{ml}$ contendo 7 esferas de sílica gel com aproximadamente $3 \mathrm{~mm}$ de diâmetro hidratadas e esterilizadas. Após agitação dos tubos por 5 minutos em aparelho tipo "vortex" para ação de quebra mecânica dos esporos, recuperouse $100 \mu \mathrm{l}$ da suspensão as quais foram adicionado mais $400 \mu \mathrm{lde}$ tampão de extração contendo $5 \mu \mathrm{l}$ de Proteinase $\mathrm{K}(10 \mathrm{mg} / \mathrm{ml})$. Os tubos foram incubados em banho-maria por 2 horas a $65^{\circ} \mathrm{C}$ e agitados a cada 20 minutos durante o período. Após a incubação, aos tubos foram adicionados $700 \mu \mathrm{l}$ de clorofórmio:álcool isoamílico (24:1) e invertidos por 5 minutos. Prosseguiu-se com centrifugação por 20 minutos a $17000 \mathrm{~g}$ na temperatura de $4{ }^{\circ} \mathrm{C}$, o sobrenadante foi transferido para novos tubos aos quais se adicionaram $500 \mu \mathrm{lde}$ isopropanol gelado $\left(-20^{\circ} \mathrm{C}\right)$ seguido por leves inversões durante 3 minutos. Os tubos permaneceram em incubação a $-20^{\circ} \mathrm{C}$ por 40 minutos e novamente centrifugados como descrito. Os pellets formados foram lavados duas vezes com etanol $70 \%$, secos a temperatura ambiente por 15 minutos e suspendidos em $50 \mu \mathrm{l}$ de tampão TE $1 \mathrm{X}$ (Tris-HCl $10 \mathrm{mM}$, EDTA $1 \mathrm{mM}, \mathrm{pH}=8,0)$ contendo $1 \mu 1$ de RNAse $(10 \mathrm{mg} / \mathrm{mL})$. A extração foi finalizada com incubação a $37^{\circ} \mathrm{C}$ por $1 \mathrm{~h}$. A integridade do DNA foi verificada em gel de agarose $0,8 \%$ corado com brometo de etídio. A quantificação foi realizada no equipamento Nanodrop 8000 (Thermo Scientific) anotando-se também a relação entre os valores de absorbância a 260 e $280 \mathrm{~nm}$.

A verificação da integridade em gel de agarose $0,8 \%$ demonstrou não haver degradação do DNA extraído (dados não apresentados) cujos valores de concentração variaram de 845,8 a $1389,3 \mathrm{mg} / \mathrm{mL}$ para os esporos recém coletados e 595,0 a $1216,3 \mathrm{mg} / \mathrm{mL}$ para os esporos preservados. Os valores de razão $\mathrm{A}_{260 / 280 \mathrm{~nm}}$ ficaram acima de 1,8 , sugerindo boa qualidade com baixa contaminação de proteínas, porém, os valores ficaram acima do ideal de 2,0, o que sugere presença de resíduos de clorofórmio (7).
As amostras foram submetidas a duas amplificações de DNA utilizando os primers desenhados por GLYNN et al. (4). Na primeira reação, específica para Puccinia de cana-de-açúcar, foram utilizados os primers forward (PkPmF 5' AAGAGTGCACTTAATTGTGGCTC 3') ancorado na região $\mathrm{ITS} 1$, e o reverse $(\mathrm{PkPmR}$ 5' TCCCACCTGATTTGAGGTCT 3') na ITS2. Esses iniciadores permitem amplificação das duas espécies de ferrugem da cana-deaçúcar com produtos esperados de tamanhos diferentes: 585 bp para P. melanocephala e 606 bp para P. kuehnii. Na segunda amplificação, específica para P. kuehnii., utilizou-se o primer forward (PkPmF 5' AAGAGTGCACTTAATTGTGGCTC 3') e o primer reverse ( $\mathrm{Pk} 1$ R 5' CAGGTAACACCTTCCTTGATGTG 3'). Essa nova combinação amplifica apenas no genoma de P. kuehnii gerando um produto de $527 \mathrm{bp}$.

As reações de amplificação foram realizadas em volumes de 50 il contendo 80 ng de DNA, 2,5 mM de $\mathrm{MgCl}_{2}, 0,25 \mathrm{mM}$ de dNTPs, 0,5 iM de cada primer, 2,5 U de Taq polimerase (Fermentas) e seu respectivo tampão 1X. Foi utilizado um termociclador Mastercycler Eppendorf programado para desnaturação inicial a $94^{\circ} \mathrm{C}$ por $5 \mathrm{~min}$, seguido por 35 ciclos de $94^{\circ} \mathrm{C}$ por $30 \mathrm{~s}, 56^{\circ} \mathrm{C}$ por $30 \mathrm{~s} \mathrm{e} 72^{\circ} \mathrm{C}$ por 30 s e uma extensão final de $72^{\circ} \mathrm{C}$ por 7 minutos. Os produtos foram revelados em gel de agarose $3 \%$ corado com brometo de etídeo.

A PCR utilizando os primers para amplificação em $P$. melanocephala e P. kuehnii foi positiva para todas as amostras apresentando apenas a banda na altura de $606 \mathrm{bp}$, confirmando a presença do agente causador da ferrugem alaranjada (Figura 1). A reação específica para P. kuehnii também foi positiva para todas as amostras. Os resultados demonstraram que o DNA é íntegro e confiável para estudos utilizando-se PCR e o congelamento de esporos a $-80^{\circ} \mathrm{C}$ por até 7 meses também não inviabiliza o sucesso da reação, porém, reduz o rendimento da concentração final de DNA extraído. A obtenção de DNA com qualidade e em altas concentrações é etapa fundamental para avaliação molecular de organismos vivos. Esse protocolo aqui definido para $P$. kuehnii deverá contribuir para estudos de identificação e caracterização da diversidade molecular deste fitopatógeno.

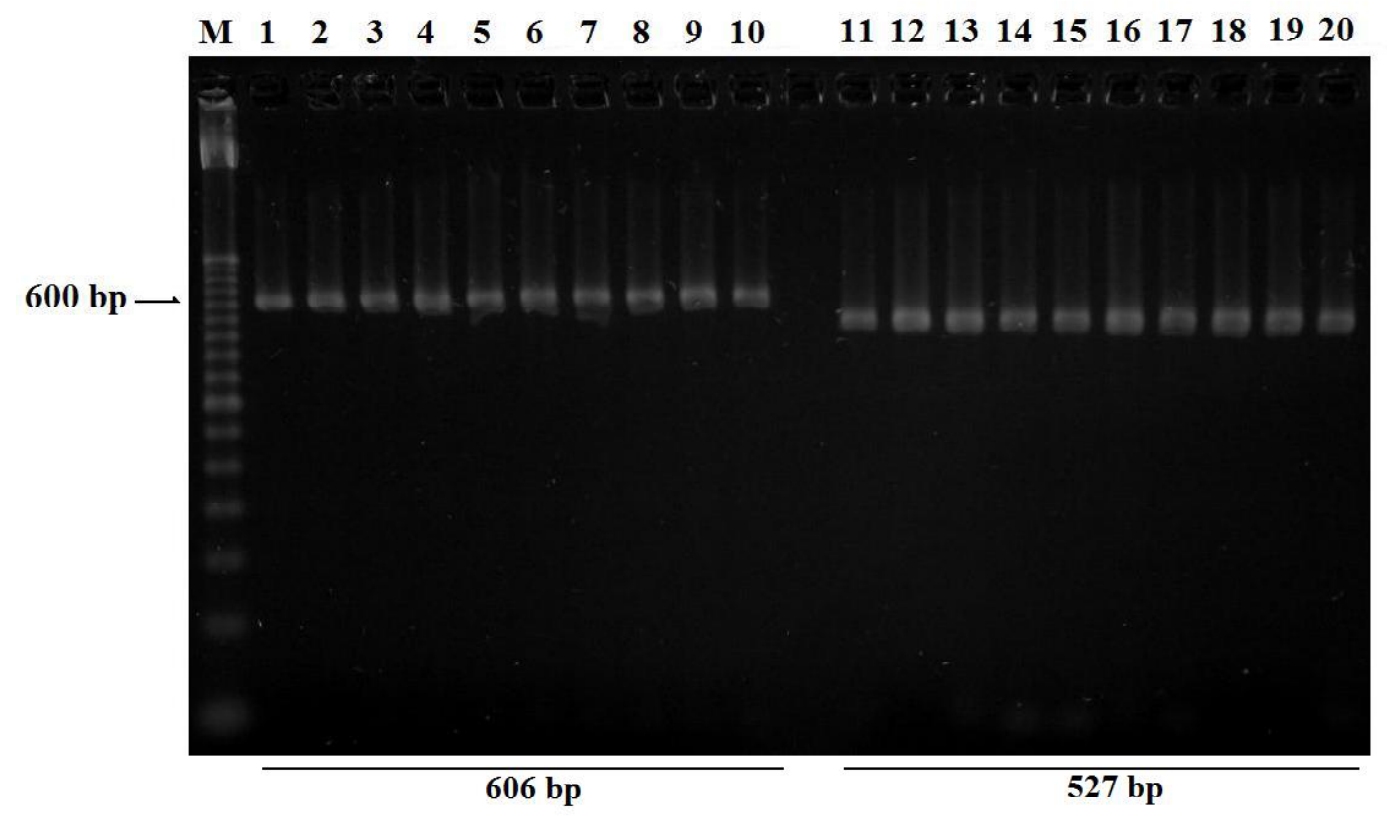

Figura 1. Gel de agarose 3\% dos produtos de amplificação de DNA extraído de esporos de Puccinia kuehnii. (M) Marcador de peso molecular 50 bp

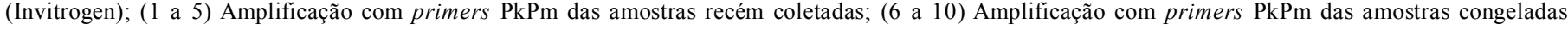

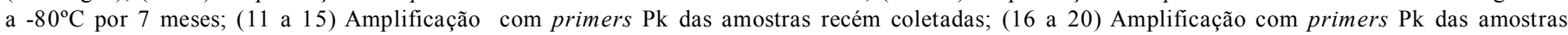
congeladas a $-80^{\circ} \mathrm{C}$ por 7 meses. 


\section{AGRADECIMENTOS}

Os autores agradecem a Financiadora de Estudos e Projetos (FINEP - 0786/09), Petrobras e ao Conselho Nacional de Desenvolvimento Cientifico (bolsa para V. M. A.) pelo suporte financeiro.

\section{REFERÊNCIAS BIBLIORÁFICAS}

1. Barbasso, D.; Jordão, H.; Maccheroni, W.; Boldini, J.; Bressiani, J.; Sanguino, A. First Report of Puccinia kuehnii, Causal Agent of Orange Rust of Sugarcane, in Brazil. Plant Disease, v. 94, n. 9, p. 1170.3-1170.3, 2010 .

2. Braithwaite, K.S.; Kroft, B.J.; Magarey, RC.; Scharaschkin, T. Phylogenetic placement of the sugarcane orange rust pathogen Puccinia kuehnii in a historical and regional context. Australasian Plant Pathology, v. 6, n. 38, p.380-388, 2009.

3. Dixon, L.J.; Castlebury, L.A.; Aime, M.C.; Glynn, N.C.; Comstock, J.C. Phylogenetic relationships of sugarcane rust fungi. Mycological Progress, v. 9, n. 4, p. 459-468, 2010.

4. Glynn, N.C.; Dixon, L.J.; Castlebury, L.A.; Szabo, L.J.; Comstock,J.C. PCR assays for the sugarcane rust pathogens
Puccinia kuehnii and P. melanocephala and detection of a SNP associated with geographical distribution in $P$. kuehnii. Plant Pathology, v. 59, n. 4, p. 703-711, 2010.

5. Magarey, R.; Willcox, T.; Croft, B.; Cordingley, A. Orange rust, a major pathogen affecting crops of Q124 in Queensland in 2000. In: Australian Society of Sugar Cane Technologists, 23., 2001. Proceedings of the Australian Society of Sugar Cane Technologists. 2001. p. 274-280.

6. Ovalle-Sáenz, W. Orozco, H.; Fong, E.; García, S. The effect of orange rust (Puccinia kuehnii) on sugar yield in six sugarcane varieties in Guatemala. In: Congress of the International Society of Sugar Cane Technologists, 27., 2010, Veracruz. Proceedings of the XXVIIth Congress of the International Society of Sugar Cane Technologists. Veracruz: ISSCT, 2010. 1 CD-ROM

7. Sambrook, J.; Russell, D.W. Molecular Cloning: a laboratory manual. 3.ed. New York: Cold Spring Harbor Laboratory Press, 2001. v. 3

8. Villaréal, L.M.M.A.; Lannou, C.; Vallavieille-Pope, C.; Neema, C. Genetic Variability in Puccinia striformis f. sp. tritici Populations Sampled on a Local Scale during Natural Epidemics. Applied and Environmental Microbiology, v.68, n. 12, p. $6138-6145,2002$ 